\title{
PENGEMBANGAN MODEL EVALUASI UNTUK MENINGKATKAN MUTU PENDIDIKAN TEKNIK ELEKTRO
}

\author{
Edy Supriyadi \\ Jurusan Pendidikan Teknik Elektro FT UNY \\ Email: edy_via@yahoo.com
}

\begin{abstract}
This study is intended to develop a model of proper evaluation, and appropriate to be used to improve the quality of education at the Study Program of Electrical Engineering Education. Method of the study is done through the study of literature, relevant research results, and applicable legislation. The study was done using a systemic approach, especially in terms of Input, Process and Output. The study results recommend to the study program of Electrical Engineering Education to develop a model evaluation, particularly the evaluation/assessment of learning outcomes, program evaluation, and self-evaluation. Evaluation model include: the establishment/strengthening of the evaluation team that can be in one unified team for the three types of evaluation, or a team of their own (separate); preparation of program evaluation; development of information systems to the level of study programs; dissemination to all concerned; drafting devices/instruments; implementation of the evaluation that is systematic and sustainable; analysing and reporting, as well as the utilization of evaluation results to improve the quality of education.
\end{abstract}

Keywords: Evaluation Model of Electrical Engineering Education

\begin{abstract}
ABSTRAK
Kajian ini dimaksudkan untuk mengembangkan model atau sistem evaluasi yang tepat, dan sesuai untuk diterapkan guna meningkatkan mutu penyelenggaraan pendidikan di program studi Pendidikan Teknik Elektro. Metode pengkajian dilakukan melalui studi literatur, hasil-hasil penelitian yang relevan, dan peraturan perundangan yang berlaku. Pengkajian dilakukan menggunakan pendekatan sistem, terutama pada aspek Input, Proses, dan Output. Hasil pengkajian merekomendasikan kepada program studi Pendidikan Teknik Elektro untuk mengembangkan model evaluasi, terutama evaluasi/penilaian hasil belajar, evaluasi program, dan evaluasi diri. Model evaluasi mencakup: pembentukan/pemantapan tim evaluasi yang bisa dalam satu tim terpadu untuk ketiga jenis evaluasi tersebut, atau tim sendiri-sendiri (terpisah); penyusunan program evaluasi; pengembangan sistem informasi untuk tingkat program studi; sosialisasi kepada semua pihak terkait; penyusunan perangkat/instrumen; pelaksanaan evaluasi yang bersifat sistematis dan berkelanjutan; analisis dan pelaporan, serta pemanfaatan hasil evaluasi untuk meningkatkan mutu penyelenggaraan pendidikan.
\end{abstract}

Kata kunci: Model Evaluasi Pendidikan Teknik elektro

\section{PENDAHULUAN}

Sumber daya manusia (SDM) merupakan faktor paling menentukan kemajuan suatu bangsa. Indonesia sebagai negara berkembang membutuhkan lebih banyak SDM berkualitas, yang menguasai ilmu pengetahuan dan teknologi sedemikian rupa sehingga dapat mengelola dan memanfaatkan sumber daya alam dengan lebih efektif dan bijaksana, serta mampu menghadapi tantangan baik internal maupun eksternal, termasuk tantangan pada era Masyarakat Ekonomi Asean (MEA).
Pemberlakukan kebijakan bebas akses barang dan tenaga kerja di negara-negara Asia Tenggara melalui MEA juga berimplikasi pada potensi meningkatnya transfer teknologi dari negara maju ke negara berkembang. Apabila SDM di Indonesia tidak mampu menguasai dan memanfaatkan teknologi tersebut, maka akan lebih banyak tenaga kerja asing yang masuk ke Indonesia. Sebaliknya, tenaga kerja Indonesia hanya akan menempati pekerjaan-pekerjaan tingkat rendahan. Berkaitan dengan hal tersebut, pendidikan di setiap jenjang, termasuk perguruan tinggi memiliki peran yang sangat penting dalam memenuhi SDM yang mampu 
berkompetisi baik di tingkat nasional, regional maupun internasional.

Undang-Undang No 12 Tahun 2012 Tentang Pendidikan Tinggi pada Pasal 5 (a, dan b) menyebutkan bahwa perguruan tinggi bertujuan untuk berkembangnya potensi Mahasiswa agar menjadi manusia yang beriman dan bertakwa kepada Tuhan Yang Maha Esa dan berakhlak mulia, sehat, berilmu, cakap, kreatif, mandiri, terampil, kompeten, dan berbudaya untuk kepentingan bangsa. Di samping itu, perguruan tinggi diharapkan menghasilkan lulusan yang menguasai cabang Ilmu Pengetahuan dan/atau Teknologi untuk memenuhi kepentingan nasional dan peningkatan daya saing bangsa.

Program Studi Pendidikan Teknik Elektro (PTE) merupakan salah satu program studi di Fakultas Teknik Universitas Negeri Yogyakarta. Lulusan Program Studi PTE diharapkan dapat menjadi pendidik pada pendidikan kejuruan, teknisi, dan pelaksana pekerjaan bidang pendidikan kejuruan dan teknik elektro berdasarkan metode ilmiah (Fakultas Teknik UNY, 2014).

Secara umum, selama ini penyelenggaraan pendidikan di program studi PTE dapat berlangsung dengan lancar. Kegiatan tridharma perguruan tinggi, meliputi pendidikan, penelitian, dan pengabdian kepada masyarakat terlaksana dengan baik. Namun demikian, hasil pelaksanaan program-program tersebut belum dicapai secara optimal. Rata-rata masa studi program S1 lebih dari 9 semester, yang mestinya 8 semester. Jumlah lulusan dengan predikat Cumlaude tergolong sedikit dibanding program studi-program studi lainnya di Fakultas Teknik UNY. Jumlah hasil penelitian program studi PTE yang dimanfaatkan pihak luar (industri, masyarakat, lembaga pendidikan, dan pihak lainnya) juga masih sangat sedikit. Dengan demikian, visi, misi, dan tujuan program studi PTE belum sepenuhnya tercapai, dan belum berfungsi sebagai pusat keunggulan (Centre of Excelence).

Evaluasi merupakan salah satu aspek penting dalam pengelolaan pendidikan, termasuk pengelolaan program studi PTE. Melalui evaluasi akan diperoleh berbagai masukan yang akurat mengenai kelayakan program, kesiapan sumber daya manusia dan fasilitas pendukung, ketepatan dan keefektivan proses pelaksanaan program, dan ketercapaian hasilnya. Belum optimalnya hasil-hasil pendidikan di program studi PTE ditengarai karena belum tepatnya rancangan program, belum optimalnya dukungan sumber daya manusia dan falititas pendukung, dan kurang efektifnya proses pelaksanaan program. Oleh karena itu, perlu dikembangkan model atau sistem evaluasi yang tepat dan dapat diterapkan serta memungkinkan terwujudnya peningkatan mutu di program studi PTE.

\section{METODE}

Metode pengkajian dilakukan melalui studi literatur, hasil-hasil penelitian yang relevan, dan peraturan perundangan yang berlaku. Pengkajian dilakukan menggunakan pendekatan sistem, terutama pada aspek Input, Proses, dan Output. Pengkajian dimulai dari identifikasi permasalahan yang dihadapi program studi PTE. Selanjutnya, dilakukan analisis terhadap berbagai faktor penyebab permasalahan tersebut, terutama yang berkaitan dengan evaluasi. Berdasarkan faktor-faktor tersebut, dikaji alternatif solusi yang paling tepat untuk mengatasi permasalahan yang dihadapi program studi PTE.

\section{HASIL DAN PEMBAHASAN}

\section{Pendidikan Tinggi}

Pendidikan memiliki peran yang sangat besar dalam mengembangkan sumber daya manusia. Pendidikan Tinggi adalah jenjang pendidikan setelah pendidikan menengah yang diselenggarakan oleh perguruan tinggi berdasarkan kebudayaan bangsa Indonesia. Pendidikan tinggi sangat penting bagi pembangunan nasional, dan dirancang untuk menghilangkan kemiskinan, meningkatkan kesehatan dan meningkatkan ekonomi masyarakat (Oxford University, 2015).

Menurut Undang-Undang Nomor 12

Tahun 2012 pasal 5, Pendidikan Tinggi bertujuan antara lain untuk berkembangnya potensi Mahasiswa agar menjadi manusia yang beriman dan bertakwa kepada Tuhan Yang Maha Esa dan berakhlak mulia, sehat, berilmu, cakap, kreatif, mandiri, terampil, kompeten, dan berbudaya untuk kepentingan bangsa. Melalui pendidikan tinggi diharapkan dapat 
dihasilkannya lulusan yang menguasai Ilmu Pengetahuan dan/atau Teknologi sesuai bidang studinya, dan menerapkannya untuk kepentingan bangsa dan negara.

Idealnya, lulusan perguruan tinggi memiliki kompetensi sesuai bidangnya, dan dengan segera dapat memperoleh pekerjaan sesuai keahliannya. Namun demikian, terdapat semacam missing link antara lulusan perguruan tinggi dengan dunia kerja. Persoalan pengangguran bukan semata karena ketiadaan pekerjaan, tetapi juga ketidaksesuaian antara jenis pekerjaan dan lulusan yang memenuhi kualifikasi yang dibutuhkan (Ali Maksum, 2015).

Sebagai salah satu upaya untuk meningkatkan kualitas penyelenggaraan pendidikan, dan kualitas lulusan, perguruan tinggi diharapkan dapat bekerjasama dengan pihak lain. Kerja sama perguruan tinggi bertujuan meningkatkan efektivitas, efisiensi, produktivitas, kreativitas, inovasi, mutu, dan relevansi pelaksanaan Tridharma Perguruan Tinggi untuk meningkatkan daya saing bangsa. Perguruan tinggi dapat melakukan kerja sama bidang akademik dan/atau bidang nonakademik dengan perguruan tinggi lain, dunia usaha, atau pihak lain, baik dalam negeri maupun luar negeri (Permendikbud Nomor 14 Tahun 2014 , Pasal 2-4).

Penyelenggaraan perguruan tinggi harus mengacu pada Standar Nasional Pendidikan Tinggi, yaitu satuan standar yang meliputi Standar Nasional Pendidikan, ditambah dengan Standar Nasional Penelitian, dan Standar Nasional Pengabdian kepada Masyarakat. Standar nasional pendidikan terkait dengan kriteria minimal tentang pembelajaran. Standar nasional penelitian berkaitan dengan sistem penelitian, dan standar nasional pengabdian masyarakat berkaitan dengan sistem pengabdian masyarakat.

Setiap perguruan tinggi diharapkan memiliki keunggulan yang khas sesuai visi dan misinya. Konsep 'keunggulan' merujuk kepada kinerja yang sangat baik atau luar biasa. Keunggulan dapat disamakan juga dengan reputasi lembaga (Brusoni, Manuela et al., 2014). Universitas Negeri Yogyakarta (UNY) merupakan salah satu lembaga pendidikan tenaga kependidikan di Indonesia. Universitas Negeri Yogyakarta menyelenggarakan program pendidikan akademik dalam sejumlah disiplin ilmu pengetahuan, teknologi, seni, dan olahraga. UNY juga menyelenggarakan pendidikan vokasi dan profesi sesuai dengan ketentuan peraturan perundang-undangan. UNY terus berusaha membenahi dan mengembangkan berbagai program unggulan yang terkait dengan Tridharma Perguruan Tinggi guna meningkatkan mutu dan relevansi lulusan, serta hasil-hasil karya penelitian yang lebih bermanfaat. Dalam beberapa tahun ke depan, UNY diharapkan menjadi World Class University, yang memiliki berbagai keunggulan. Program Studi Pendidikan Teknik Elektro (PTE) merupakan salah satu program studi yang ada di Fakultas Teknik Universitas Negeri Yogyakarta. Visi Program Studi PTE adalah pada tahun 2025 menjadi Program Studi yang unggul dan kompetitif di tingkat internasional dalam menghasilkan tenaga pendidik yang bertaqwa, mandiri, cendekia serta adaptif terhadap perkembangan Ilmu Pengetahuan Teknologi dan Seni (Fakultas Teknik UNY, 2014). Misi Program Studi Pendidikan Teknik Elektro antara lain: menyelenggarakan pendidikan teknik elektro yang berkualitas, mempersiapkan tenaga pendidik teknik elektro yang unggul dan berdaya saing sesuai tuntutan kompetensi dunia kerja, dan mengembangkan sistem pendidikan teknik elektro melalui kerjasama penelitian dengan pemangku kepentingan. Implementasi sistem pendidikan nasional yang dilakukan di Program Studi Pendidikan Teknik Elektro (S1) pada setiap level kualifikasi KKNI Level 6 mencakup proses yang menumbuhkembangkan sikap, pengetahuan, ketrampilan khusus dan ketrampilan khusus umum.

\section{Mutu Pendidikan Tinggi}

Menurut Undang-Undang No. 12 Tahun 2012 Pasal 51, pendidikan tinggi yang bermutu merupakan pendidikan tinggi yang menghasilkan lulusan yang mampu secara aktif mengembangkan potensinya dan menghasilkan ilmu pengetahuan dan/atau teknologi yang berguna bagi masyarakat, bangsa, dan negara. Schindler, L., Puls-Elvidge, S., Welzant, H., \& Crawford, L. (2015) mengembangkan konsep kualitas pada pendidikan tinggi ditinjau dari empat aspek, yaitu quality as purposeful, exceptional, transformative, and accountable. Kualitas sebagai purposeful berkaitan dengan produk dan layanan perguruan tinggi sesuai 
dengan visi/misi, tujuan, persyaratan, akreditasi, dan standar yang telah ditetapkan. Kualitas sebagai exceptional mengarah pada tingkat pelayanan dan produk perguruan tinggi yang luar biasa, memiliki makna tingkat keunggulan yang tidak dapat dicapai oleh sebagian besar perguruan tinggi lainnya. Kualitas dari aspek transformative bermakna pelayanan dan produk perguruan tinggi memberikan perubahan positif terhadap mahasiswa, meliputi afektif, kognitif, dan psikomotorik, serta potensi profesional. Kualitas dari aspek accountable berkaitan dengan akuntabilitas penggunaan fasilitas, pelayanan, dan produk perguruan tinggi terhadap semua pihak terkait (stakeholders).

Pendidikan yang berkualitas mencakup kualitas: pembelajar, lingkungan pembelajaran, konten (isi), proses, dan hasil (UNICEF, 2000). Peserta didik yang sehat, bergizi baik dan siap untuk berpartisipasi dan belajar, dan didukung dalam pembelajaran oleh keluarga dan komunitas mereka. Lingkungan yang sehat, aman, pelindung dan peka gender, dan menyediakan sumber daya yang memadai dan fasilitas. Konten yang tercermin dalam kurikulum yang relevan dan bahan untuk akuisisi keterampilan dasar, terutama di bidang literasi, berhitung dan keterampilan untuk hidup, dan pengetahuan di bidang-bidang seperti jenis kelamin, kesehatan, gizi. Proses pembelajaran efektif merupakan hal penting dan sangat menentukan hasil pembelajaran. Hasil yang mencakup pengetahuan, keterampilan dan sikap, dan terkait dengan tujuan nasional untuk pendidikan dan partisipasi positif dalam masyarakat.

Pembelajaran yang efektif adalah pembelajaran yang dapat meningkatkan pencapaian kompetensi siswa sedemikian rupa sehingga dapat menunjang keberhasilan siswa di masa mendatang. (Coe, Robert et al., 2014). Proses pembelajaran dikembangkan sesuai dengan karakteristik dan tujuan Kurikulum. Proses Pembelajaran diselenggarakan secara interaktif, inspiratif, menyenangkan, menantang, memotivasi peserta didik untuk berpartisipasi aktif. Untuk itu perlu dilakukan perencanaan pembelajaran, pelaksanaan proses pembelajaran serta penilaian proses pembelajaran untuk meningkatkan efisiensi dan efektivitas ketercapaian kompetensi lulusan.

Menurut The International Council of

Systems Engineering (Ravitz,at al., 2013), sistem merupakan konstruksi atau kumpulan elemen-elemen yang secara bersama-sama mengarah pada pencapaian tujuan. Elemenelemen tersebut bisa dalam bentuk manusia, fasilitas, perangkat keras, perangkat lunak, kebijakan, pembiayaan, dan hal lainnya yang diperlukan untuk mencapai atau menghasilkan sesuatu.

Penyelenggaraan pendidikan dalam perspektif sistemik terdiri atas Input, Proses, dan Output. Input dibedakan menjadi dua, yaitu raw input, dan instrumental input. Raw input adalah peserta didik atau mahasiswa. Instrumental input meliputi tenaga pengajar, kurikulum, sarana dan prasarana, sumber dan media pembelajaran, serta dukungan terkait lainnya. Proses merupakan komponen esensial, yaitu proses pelaksanaan dan pengelolaan semua kegiatan pembelajaran dengan dukungan input untuk mencapai output/hasil atau kompetensi mahasiswa seperti yang direncanakan. Idealnya, jika program-program, termasuk tridharma perguruan tinggi dirancangan dengan baik, dan komponen input dipenuhi, serta proses pelaksanaan program berlangsung dengan baik, maka akan dihasilkan output yang baik.

\section{Evaluasi}

Evaluasi adalah prosedur yang digunakan untuk menentukan apakah subjek memenuhi kualifikasi sesuai kriteria yang telah ditetapkan (Bob Kizlik, 2012). Prosedur tersebut dilakukan melalui langkah-langkah perencanaan, penyusunan perangkat, pengumpulan informasi melalui sejumlah bukti yang terkait dengan tujuan evaluasi, pengolahan, dan penggunaan informasi tentang hasil evaluasi. Evaluasi sangat terkait dengan pengambilan keputusan atau kebijakan. Pengambilan keputusan merupakan tindakan yang diambil berdasarkan data atau informasi yang telah diperoleh. Keputusan atau kebijakan yang baik memerlukan hasil evaluasi yang baik.

Berkaitan dengan penyelenggaraan pendidikan di perguruan tinggi, evaluasi dapat dilakukan untuk mengetahui hasil belajar peserta didik, efektivitas program-program pendidikan, dan internal kondisi perguruan tinggi (evaluasi diri). Evaluasi atau penilaian hasil belajar peserta didik dilakukan oleh setiap Dosen, dan dalam hal tertentu dilakukan oleh suatu tim dosen atau gabungan tim dosen 
dengan pihak eksternal. Evaluasi program dilakukan untuk mengetahui efektivitas program-program yang diselenggarakan oleh perguruan tinggi. Evaluasi diri dilakukan untuk mengetahui kinerja dan kondisi perguruan tinggi, baik pada tingkatan program studi, fakultas, maupun lembaga (universitas/institut/sekolah tinggi, dsbnya).

\section{a. Penilaian Hasil Belajar}

Hasil belajar adalah suatu proses usaha yang dilakukan seseorang untuk memperoleh suatu perubahan tingkah laku yang baru sebagai hasil pengalamannya sendiri dalam interaksi dengan lingkungannya. Angelo, T.A. \& Cross, P.K. (1993) menjelaskan bahwa, hasil belajar adalah kemampuan dalam bentuk tingkah laku siswa berupa kognitif, afektif dan psikomotor setelah menerima pengalaman belajar.

Dalam konteks pencapaian hasil belajar, terdapat istilah penilaian/asesmen, dan evaluasi. Menurut Safari (1998), penilaian adalah penggunaan teknik penilaian (tes: tertulis, lisan/wawancara, perbuatan/praktik; pengamatan/observasi) untuk memperoleh informasi tentang kemampuan peserta didik. Evaluasi adalah kegiatan untuk mengetahui apakah suatu program telah berhasil dan efisien dan efektif atau tidak. Penilaian merupakan kegiatan untuk memperoleh informasi tentang pencapaian dan kemajuan belajar peserta didik dan mengefektifkan penggunaan informasi tersebut untuk mencapai tujuan pendidikan. Evaluasi mencakup proses pembuatan keputusan tentang kedudukan dan performance peserta didik. Pengukuran (measurement) adalah kegiatan untuk mendapatkan informasi secara kuantitatif atau dengan kata lain merupakan prosedur untuk menentukan skor peserta didik.

Penilaian hasil belajar merupakan proses sistematis dalam mengumpulkan, menganalisis dan menginterpretasi informasi untuk menentukan sejauhmana mahasiswa telah mencapai tujuan pembelajaran, dan hasilnya dimanfaatkan oleh dan mahasiswa untuk mengoptimalkan efektifitas pembelajaran (Gronlund and Linn, 1990). Penilaian dirancang dan dilaksanakan oleh masing-masing tenaga pengajar sesuai mata kuliahnya.

Penilaian dirancang untuk membantu para tenaga pengajar dalam memperoleh informasi yang akurat tentang apa yang dipelajari mahasiswa, dan sejauhmana mereka berhasil menguasai materi pembelajaran. Penilaian memiliki setidaknya tujuh ciri, yaitu: berpusat pada pesertadidik, otonomi , bermanfaat ganda, formatif, kontekstual, dan berkelanjutan.

Terdapat tiga pendekatan dalam pelaksanaan penilaian, yaitu assessment of learning, assessment for learning, dan assessment as learning. Assessment of learning merupakan penilaian yang dilaksanakan setelah proses pembelajaran selesai. Proses pembelajaran selesai tidak selalu terjadi di akhir tahun atau di akhir peserta didik menyelesaikan pendidikan pada jenjang tertentu. Setiap Dosen melakukan penilaian yang dimaksudkan untuk memberikan pengakuan terhadap pencapaian hasil belajar setelah proses pembelajaran selesai, berarti guru tersebut melakukan assessment of learning. Ujian Akhir Semester, dan berbagai bentuk penilaian sumatif merupakan assessment of learning.

Assessment for learning dilakukan selama proses pembelajaran berlangsung dan biasanya digunakan sebagai dasar untuk melakukan perbaikan proses belajar mengajar. Dengan assessment for learning Dosen dapat memberikan umpan balik terhadap proses belajar peserta didik, memantau kemajuan, dan menentukan kemajuan belajarnya. Assessment for learning juga dapat dimanfaatkan oleh guru untuk meningkatkan performan dalam memfasilitasi peserta didik. Berbagai bentuk penilaian formatif, misalnya tugas, presentasi, proyek, termasuk kuis merupakan contohcontoh assessment for learning (penilaian untuk proses belajar).

Assessment as learning mirip dengan assessment for learning, karena juga dilaksanakan selama proses pembelajaran berlangsung. Bedanya, assessment as learning melibatkan siswa secara aktif dalam kegiatan penilaian tersebut. Siswa diberi pengalaman untuk belajar menjadi penilai bagi dirinya sendiri. Penilaian diri (self assessment) dan penilaian antar teman merupakan contoh assessment as learning.

Berdasarkan penggunaannya dalam pembelajaran, penilaian dibedakan menjadi penilaian penempatan, formatif, diagnostik, dan sumatif. Penilaian penempatan umumnya dilakukan pada awal pembelajaran, yaitu untuk menentukan kesesuaian kemampuan yang disyaratkan, tingkat penguasaan tujuan 
pelajaran, dan model pembelajaran terbaik. Penilain formatif umumnya dilakukan selama berlangsungnya pembelajaran, yang bertujuan untuk memberikan umpan balik guna meningkatkan pembelajaran, dan memperbaiki kekeliruan pembelajaran. Penilaian diagnostik digunakan untuk menentukan penyebabpenyebab (intelektual, fisik, emosi, lingkungan) kesulitan-kesulitan belajar yang seringkali ditemui. Penilaian sumatif digunakan untuk menentukan pencapaian hasil akhir pembelajaran, penentuan nilai atau sertifikasi penguasaan tujuan-tujuan pembelajaran tersebut

\section{b. Evaluasi Program}

Setiap lembaga pendidikan, termasuk perguruan tingg pasti memiliki sejumlah program yang harus dilaksanakan. Program adalah suatu rencana yang melibatkan berbagai unit yang berisi kebijakan dan rangkaian kegiatan yang harus dilakukan dalam kurun waktu tertentu. Rancangan dan pelaksanaan program juga perlu dievaluasi. Evaluasi program merupakan serangkaian kegiatan untuk mengumpulkan informasi tentang implementasi suatu program secara sistematis, dan berkesinambungan guna memperoleh informasi yang akurat mengenai efektivitas program tersebut untuk kepentingan pengambilan keputusan.

Program akan dapat mencapai hasil secara optimal seperti yang diharapkan apabila program tersebut dirancang dan dilaksanakan dengan baik. Penyelenggaraan program perlu dikelola dan dipantau secara teratur sehingga apabila terdapat penyimpangan atau kendala dapat segera diketahui dan diperbaiki. Demikian pula setiap program perlu dievaluasi secara komprehensif agar dapat diketahui sejauhmana efektivitas dan efisiensinya.

Tujuan diselenggarakannya evaluasi program adalah memantau proses kegiatan sehingga dapat mengetahui keadaan, perkembangan dan masalah yang ditemui dalam setiap pelaksanaan program. Di samping itu, melalui evaluasi program akan diperoleh berbagai masukan guna mengatasi masalah yang dihadapi dan meningkatkan mutu penyelenggraan program, dan berbagai informasi penting bagi pengambil keputusan dalam menentukan suatu kebijakan yang terkait dengan program. Berdasarkan hasil evaluasi dapat dilakukan peningkatan program di masa mendatang, dan menentukan apakah sebuah program harus dilanjutkan atau dihentikan.

Menurut Kirkpatrick and Kirkpatrick (2009) faktor-faktor berikut ini harus dipertimbangkan ketika merencanakan dan melaksanakan program, termasuk program pelatihan yang efektif, yaitu: Menentukan kebutuhan, Menetapkan tujuan, Menentukan isi pelajaran, Memilih peserta, Menentukan terbaik jadwal, Memilih fasilitas yang sesuai, Memilih instruktur yang sesuai, Memilih dan mempersiapkan bantuan audiovisual, Mengkoordinasikan program, dan Mengevaluasi program

Kaufan dan Thomas (Suharsini Arikunto dan Cepi Safrudin, 2007:24) membedakan model evluasi program menjadi delapan, yaitu: Goal Oriented Eavaluation Model, Goal Free Eavaluation Model, Formatif Summatif Evaluation Model, Countenance Evaluation Model, Responsif Evaluation Model, SSE-UCLA Evaluation Model, CIPP Evaluation Model(Context Input Process Product), dan Discrepancy Model.

Program dibedakan dibedakan menjadi berdasarkan jenis kegiatannya, yaitu program pemrosesan (mengubah sesuatu yang dianggap bahan mentah menjadi sesuatu yang dianggap barang jadi), program layanan (program yang bertujuan memberikan kepuasan pada pihak lain), dan program umum (program yang yang bersifat umum, tidak memiliki spesifikasi sebagaimana program pemprosesan dan program layanan). Ketepatan penentuan model evaluasi program bergantung pada jenis kegiatannya. Oleh karena itu tidak semua model evaluasi program dapat diterapkan.

\section{c. Evaluasi Diri}

Berkaitan dengan penyelenggaraan pendidikan di perguruan tinggi, secara umum evaluasi diri dimaknai sebagai suatu proses pengumpulan serta pemrosesan data dan informasi yang akan digunakan sebagai dasar pengambilkan keputusan, pengelolaan dan pengembangan program studi/perguruan tinggi (BAN PT, 2010). Evaluasi diri dilakukan untuk memperoleh informasi, termasuk masukan yang akurat untuk meningkatkan mutu program studi. Setiap perguruan tinggi diharapkan melakukan 
evaluasi diri, baik untuk kepentingan internal maupun untuk kepentingan akreditasi.

Tujuan utama dari evaluasi diri adalah untuk membantu perguruan tinggi tinggi memastikan bahwa mereka memenuhi standar kualitas yang ditetapkan, dan mengetahui perbaikan atau penyempurnaan yang perlu dilakukan, mencakup kebijakan, proses, program, layanan, fasilitas, dan sumber daya manusia, serta hal terkait lainnya. Melalui evaluasi diri akan diperoleh gambaran mengenai kinerja dan keadaan dirinya melalui pengkajian dan analisis yang dilakukan oleh program studi/perguruan tinggi sendiri berkenaan dengan kekuatan, kelemahan, peluang, tantangan, kendala, bahkan ancaman. Pengkajian dan analisis itu dapat dilaksanakan dengan memanfaatkan pakar sejawat dari luar program studi/perguruan tinggi, sehingga evaluasi-diri dapat dilaksanakan secara objektif.

Menurut Sobhi Abou Chahine, et al (2008), proses evaluasi diri harus prospektif dan terstruktur dengan baik jika ingin mendapatkan manfaat yang maksimal. Tahapan utama dalam proses evaluasi diri meliputi: Memilih jenis model evaluasi diri (dijelaskan secara singkat pada bagian berikutnya) yang akan sangat berguna untuk lembaga dalam mendukung dan mempromosikan tujuan dan prioritas khususnya; Membangun dan mengorganisir komite yang diperlukan dan partisipasi kampuslebar untuk keterlibatan efektif masyarakat kelembagaan seluruh; Melaksanakan proses; Menulis laporan meringkas kesimpulan dan rekomendasi; Mengembangkan rencana mutu strategis untuk mempertahankan kekuatan, dan mengatasi masalah/kelemahan; tim evaluasi diri melakukan review terhadap hasil evaluasi diri kaitannya dengan misi lembaga; Menanggapi laporan dari tim evaluasi diri; Menunggu keputusan badan akreditasi mengenai akreditasi.

\section{Pengembangan Sistem Evaluasi PTE}

Evaluasi sangat penting dalam penyelenggaraan program-program di program studi Pendidikan Teknik Elektro, terutama yang terkait dengan Tri Dharma Perguruan Tinggi, yaitu Pendidikan, Penelitian, dan pengabdian kepada masyarakat. Dalam konteks peningkatan mutu, setidaknya terdapat tiga jenis evaluasi yang perlu dikembangkan, yaitu: evaluasi atau penilaian hasil belajar, evaluasi program, dan evaluasi diri.

\section{a. Penilaian Hasil Belajar}

Penilaian merupakan proses perolehan/pengumpulan informasi tentang hasil-hasil belajar siswa yang digunakan sebagai pedoman untuk mengambil keputusan akademik tentang siswa, memberikan informasi pada siswa, orang tua siswa, para guru, atau pihak-pihak terkait lainnya tentang kemajuan belajar siswa, keunggulan dan kelemahannya, untuk menentukan efektivitas pembelajaran dan kurikulum, serta menginformasikan kebijakan.

Pengembangan penilaian hasil belajar perlu dilakukan dengan langkah-langkah secara garis besar sebagai berikut:

\section{1) Pembentukan/pemantapan Tim Penilaian Hasil Belajar di Tingkat Program Studi}

Tim penilaian hasil belajar di tingkat prodi perlu dibentuk secara resmi oleh internal program studi. Tim terdiri atas Dosen yang memiliki keahlian di bidang penilaian/pengukuran, dan perwakilan rumpun keahlian, serta karyawan yang akan membantu teknis pelaksanaannya. Tim ini bertanggung jawab dalam mengkoordinasi penyusunan program, pengembangan perangkat, pengelolaan sistem informasi penilaian, pelaksanaan penilaian, dan pelaporan serta pemanfaatan hasil penilaian.

\section{2) Penyusunan program penilaian}

Program penilaian perlu disusun dan atau diperbarui setidaknya setiap semester. Program penilaian sangat penting karena dapat digunakan sebagai pedoman bagi civitas akademika dalam melaksanakan kegiatankegiatan yang terkait dengan penilaian hasil belajar. Program berisi antara lain: tujuan penilaian, jenis, ruang lingkup, sasaran, perangkat, jadwal, pengelolaan/sistem informasi penilaian, laporan, pemanfaatan hasil penilaian, pembagian tugas, dan hal terkait lainnya. Piminan program studi dan tim penilaian mengkoordinasikan penyusunan program penilaian untuk tingkat program studi.

\section{3) Pengembangan sistem informasi penilaian}

Sistem informasi penilaian perlu dikembangkan tersendiri, atau terpadu dengan 
sistem informasi yang telah ada di program studi. Sistem informasi sangat penting, terutama dalam pendokumentasian program, perangkat penilaian, rancangan penilaian setiap mata kuliah, daftar nilai, pengolahan hasil penilaian, pelaporan, dan kepentingan lainnya. Melalui sistem informasi, setiap Dosen dapat menyimpan perangkat penilaian dan data hasil penilaian, serta memperbaruinya. Mahasiswa juga dapat melihat kemajuan belajarnya dengan melihat nilai-nilai penugasan, ulangan harian, ujian tengah semester, dan sebagainya. Pimpinan program studi dapat memeriksa keaktivan para Dosen dalam melakukan penilaian, dan melihat kemajuan belajar mahasiswa. Berdasarkan hasil penilaian yang ada pada sistem informasi, pimpinan dan dosen dapat mengadakan program yang sesuai. Misalnya program remedi, pengayaan, rapat, seminar, dan kegiatan lain yang terkait dengan peningkatan mutu pendidikan di program studi.

\section{4) Sosialisasi}

Setiap warga program studi, baik dosen maupun karyawan hendaknya memahami dan secara aktif terlibat dalam penilaian sesuai tugas dan fungsinya. Oleh karena itu, sistem penilaian hasil belajar perlu disosialisasikan dengan baik. Sosialisasi bisa dilakukan pada saat ada kesempatan, misalnya: rapat program studi, Forum Group Disccussion, atau acara khusus sosialisasi dengan program-program lainnya (evaluasi program dan evaluasi diri/SPMI).

\section{5) Pengembangan rancangan penilaian setiap mata kuliah}

Setiap mata kuliah hendaknya dilengkapi dengan rancangan penilaian. Rancangan penilaian umumnya terpadu dalam Rencana Perkuliahan Semester. Namun demikian, rancangan penilaian dilengkapi juga dengan perangkat instrumennya, dan pedoman penilaian/pensekorannya. Program studi perlu mengembangkan format dan ruang lingkup rancangan penilaian. Rancangan penilaian tiap mata kuliah perlu diinformasikan kepada mahasiswa pada saat pertemuan di awal kuliah.

\section{6) Pengembangan intrumen/soal penilaian}

Instrumen/soal, baik berupa tes maupun non tes untuk setiap mata kuliah perlu dikembangkan. Tim penilaian hendaknya mengkoordinasi proses pengembangan instrumen, termasuk validasi agar dihasilkan instrumen yang sahih dan handal. Setiap mata kuliah, meskipun pengajarnya lebih dari satu, hendaknya menggunakan perangkat soal yang sama dalam pelaksanaan pengujiannya. Instrumen dikembangkan secara sistematis. Jika memungkinkan dilakukan sesuai dengan prosedur pengembangan instrumen baku. Instrumen harus valid, reliablel, fokus pada kompetensi yang diharapkan, komprehensif, obyektif, berkesinambungan, dan mendidik.

\section{7) Pelaksanaan penilaian yang terpadu dengan pembelajaran}

Penilaian dilakukan secara sistematis dan berkesinambungan melalui placement test (tes awal dan penempatan), formative, diagnostics dan summatif. Prosedur pelaksanaannya sesuai dengan tujuan dan rangkaian pembelajaran dengan prinsip integrating assessment and learning process. Teknik penilaian menggunakan on going assessment dengan multi metode meliputi penilaian proses dan produk, antara lain: paper and pencil test, performance test, portfolio, individual oral presentations, quiz, debates, field work reports, mind maps, talk and answer sessions, yang dilakukan baik secara formal maupun informal. Bentuk instrumen yang digunakan disesuaikan dengan metode dan karakteristik kompetensi yang diukur. Penilaian hendaknya dilakukan terpadu dengan pembelajaran, terutama untuk penilaian formatif, sesuai rancangan penilaian setiap mata kuliah. Fungsi assessment for learning, dan assessment as learning perlu lebih diintensifkan untuk penyempurnaan kegiatan pembelajaran.

\section{8) Pelaksanaan penilaian tengah semester, dan akhir semester}

Penilaian tengah semester, dan akhir semester perlu dilakukaan secara sistematis sesuai rancangan dan jadwal yang telah disusun. Instrumen/soal yang digunakan hendaknya instrumen yang telah disusun dan divalidasi. Penilaian tengah semester 
hendaknya dilakukan serentak pada minggu ke8 atau waktu yang ditentukan sesuai rancangan. Pelaksanaan penilaian secara serentak sekaligus sebagai upaya agar setiap dosen melaksanakan proses pembelajaran sesuai yang disusun dalam Rancangan Perkuliahan/Pembelajaran Semester (RPS). Hasil penilaian tengah semester juga perlu di input ke sistem informasi, dan atau diberikan kembali ke mahasiswa sebagai umpan balik, baik bagi mahasiswa maupun dosen pengajarnya. Ulangan akhir semester dilaksanakan sesuai jadwal, yang umumnya telah ditentukan sesuai kalender akademik. Pelaksanaan ulangan akhir semester, terutama untuk tim dosen yang mengajar mata kuliah yang sama, hendaknya menggunakan perangkat soal yang sama. Petugas pengawas penilaian akhir semester hendaknya disiplin dalam melaksanakan tugasnya, namun tidak mengganggu kenyamanan mahasiswa dalam mengerjakan soal ujian.

\section{9) Pelaporan dan Pemanfaatan Penilaian Hasil belajar}

Setiap dosen hendaknya segera memeriksa pekerjaan/penilaian mahasiswa, dan mendokumentasikan hasil penilaian serta memanfaatkannya untuk kepentingan pembelajaran.Hasil penilaian harus diinformasikan kepada mahasiswa agar bisa mengetahui materi-materi yang sudah dikuasai, dan yang belum dikuasai sehingga mahasiswa bisa belajar lebih baik. Aspek transparansi perlu untuk dikedepankan, meskipun harus tetap menjaga etika penilaian. Hasil penilaian, baik formatif maupun sumatif sebaiknya disimpan di sistem informasi. Dengan demikian, disamping pengajar, pimpinan program studi juga dapat memantau kemajuan belajar mahasiswa. Program pengayaan dan remedi perlu dilakukan sesuai dengan hasil penilaian.

\section{b. Evaluasi Program, dan Evaluasi Diri Program Studi}

Program studi umumnya memiliki beberapa program, baik untuk setiap semester atau setiap tahun. Program-program tersebut berkaitan dengan standar perguruan tinggi yang telah ditetapkan. Beberapa program diantaranya: peningkatan kualitas tenaga pengajar, perkuliahan, penelitian, pengabdian pada masyarakat, sarana prasarana, artikel/jurnal, kompetensi lulusan, kerjasama, dan program-program terkait lainnya. Data yang akurat tentang pelaksanaan program dan hasilnya sangat diperlukan dalam upaya peningkatan mutu.

Secara internal, program studi perlu melakukan evaluasi diri. Evaluasi diri merupakan suatu proses untuk membantu program studi, dan terpadu dengan sistem manajemen rutin. Evaluasi diri berkaitan dengan proses pengkajian internal institusi (program studi), secara kolaboratif, menyeluruh, dan reflektif.

Sebaiknya evaluasi program dan evaluasi diri dilakukan terpadu dengan sistem penjaminan mutu internal (SPMI) program studi. Berkaitan dengan pengembangan evaluasi program dan evaluasi diri, program studi hendaknya melakukan sebagai berikut:

\section{1) Pembentukan Tim di Tingkat Prodi}

Program studi sebaiknya melakukan pembentukan/pemantapan Tim Evaluasi Program, dan Evaluasi Diri. Tim tersebut sebaiknya terpadu menjadi satu tim, yaitu Tim SPMI (Sistem Penjaminan Mutu Intenal). Tim SPMI sangat penting untuk mendukung program studi dalam perencanaan, penerapan, pengendalian, dan pengembangan standar mutu pengelolaan pendidikan secara konsisten dan berkelanjutan, sehingga semua pihak terkait memperoleh kepuasan. Tim SPMI program studi sebaiknya terdiri atas pimpinan, dan beberapa dosen serta dibantu oleh karyawan. Tim SPMI hendaknya memperoleh pelatihan tentang evaluasi program, evaluasi diri, dan penjaminan mutu.

\section{2) Penyusunan program}

Program SPMI, terutama untuk evaluasi program dan evaluasi diri di tingkat program studi perlu disusun secara komprehensif, dan sesuai dengan programprogram tridharma perguruan tinggi yang telah dirancang. Evaluasi diri perlu secara rutin dilakukan, dan tidak hanya pada saat menghadapi akreditasi. Penyusunan program evaluasi program, dan evaluasi diri hendaknya bersifat terpadu. Evaluasi diri dilakukan bukan semata-mata untuk kepentingan akreditasi. 
Justru yang tidak kalah pentingnya adalah untuk kepentingan penyempurnaan pelaksanaan dan hasil program, yang pada akharnya secara akumulatif mengarah pada peningkatan mutu dan relevansi lulusan sesuai visi, misi, dan tujuan program studi.

\section{3) Sosialisasi}

Keberhasilan penyelenggaraan pendidikan sangat tergantung juga pada partisipasi aktif seluruh warga program studi. Oleh karena itu, pimpinan, tenaga pengajar, dan karyawan harus memahami secara komprehensif tentang visi, misi, tujuan dan program-program yang perlu dilaksanakan, serta partisipasi segenap civitas akademika. Seperti sosialisasi pada penilaian hasil belajar, sosialisasi tentang SPMI perlu dilakukan secara terpadu.

\section{4) Pengembangan perangkat evaluasi diri, dan evaluasi program program}

Tim SPMI bekerjasama dengan pimpinan dan civitas akademika program studi perlu mengembangkan perangkat SPMI, termasuk untuk evaluasi diri, dan evaluasi program. Dokumen SPMI meliputi: dokumen kebijakan SPMI, manual SPMI, dokumen standar dalam SPMI, dokumen formulir yang digunakan dalam SPMI. Dokumen tersebut seharusnya telah disusun tingkat universitas, dan fakultas. Program studi dapat menggunakan dokumen SPMI tingkat Fakultas, dan atau memodifikasi sesuai karakteristik program studi. Perangkat evaluasi program harus dikembangkan sesuai program-program yang diselenggarakan oleh program studi.

\section{5) Pelaksanaan evaluasi program, dan evaluasi diri}

Pelaksanaan evaluasi program sebaiknya tidak hanya pada akhir pelaksanaan program. Pemantauan terhadap proses pelasksanaan program perlu dilakukan untuk memberikan masukan perbaikan sehingga program dapat berlangsung dengan baik. Salah satu unsur penjaminan mutu internal dilakukan melalui pemantauan terhadap pelaksanaan program. Evaluasi diri dilakukan sesuai jadwal yang telah disusun. Komponen-komponen untuk kepentingan akreditasi perlu diperhatikan dalam evaluasi diri. Temuan hasil evaluasi diri perlu segera disampaikan ke pihak terkait untuk segera ditindaklanjuti dan dilakukan perbaikan.

\section{6) Pelaporan dan pemanfaatan hasil evaluasi program, dan evaluasi diri}

Hasil evaluasi program, terutama pada saat pemantauan pelaksanaan program perlu segera ditindaklanjuti. Temuan tentang hambatan atau ketidaksesuaian pelaksanaan program perlu dilengkapi dengan alternatif solusinya sehingga dengan segera permasalahan yang ada bisa diatasi. Hasil evaluasi program pada tahap sumatif atau akhir program perlu dikaji bersama oleh semua pihak terkait untuk kepentingan perencanaan program-program tahun berikutnya. Hasil evaluasi diri, terutama untuk kepentingan akreditasi perlu disusun sesuai dengan format yang telah ditentukan. Secara akumulatif, hasil evaluasi program dan evaluasi diri bisa saling melengkapi, untuk digunakan untuk penyempurnaan programprogram tahun berikutnya.

\section{SIMPULAN}

Evaluasi sangat penting dalam penyelenggaraan dan peningkatan mutu pendidikan di perguruan tinggi, termasuk pada program studi Pendidikan Teknik Elektro. Program studi hendaknya mengembangkan sistem evaluasi, terutama evaluasi/penilaian hasil belajar, evaluasi program, dan evaluasi diri.

Program studi perlu segera membentuk Tim Evaluasi Hasil Belajar, Evaluasi Program, dan Evaluasi Diri, yang bisa dalam satu tim terpadu untuk ketiga jenis evaluasi tersebut, atau tim sendiri-sendiri (terpisah). Sistem informasi untuk ketiga jenis evaluasi tersebut perlu dikembangkan untuk tingkat program studi agar pengelolaan perancangan, pelaksanaan, dan pemanfaatan hasil evaluasi bisa optimal.

Tim Evaluasi dan pimpinan program studi hendaknya mengkoordinasi penyusunan program dan pengembangan perangkat evaluasi, serta melengkapi fasilitas pendukung guna meningkatkan efektivitas pelaksanaan dan hasil program. Pelaksanaan evaluasi hendaknya bersifat sistematis dan berkelanjutan sehingga hasilnya dapat segera dimanfaatkan untuk penyempurnaan program dan implementasinya. 


\section{DAFTAR RUJUKAN}

Aiken, Lewis R. 1998. Psychological Testing and Assessment. New Jersey: PrenticeHall.

Ali Maksum. 2015. Kurikulum dan

Pembelajaran di Perguruan Tinggi:

Menuju Pendidikan yang

Memberdayakan.

https://www.researchgate. net/publication/303912143.

Diunduh pada 9 Januari 2017.

Angelo, T.A. \& Cross, P.K. 1993., Classroom Assessment Techniques. A Handbook for College Teachers (2nd Ed.), California: Jossey-Bass.

BAN PT. 2010. Pedoman Evaluasi-Diri Untuk Akreditasi Program Studi Dan Institusi Perguruan Tinggi

Brusoni, Manuela et al. 2014. The Concept Of

Excellence In Higher Education. Belgium: ENQA AISBL.

Chahine, Sobhi Abou et al. 2008. Quality Assurance for Higher Education in Lebanon. Project Report funded by the EC under the Tempus Framework. http://www.higher-edu.gov.lb/projects/ Tempus/QAHEL/guide\%20II\%20QAHEL.pdf.

Diunduh 10 Januari 2017.

Coe, Robert et al. 2014. What makes great teaching? Review of the underpinning research. Durham University.

Fakultas Teknik UNY. 2014. Kurikulum 2014 Program Studi Pendidikan Teknik elektro (S1), Pendidikan Teknik Mekatronika (S1), Teknik Listrik (D3) Jurusan Pendidikan Teknik Elektro. Yogyakarta: FT UNY.

Gronlund, Norman E., dan Linn Joyce E. 1990. Measurement and Evaluation in Teaching. New Jersey: Mcmillan Publishing Company.

Harris Duncan, and Bell, Chris. 1994.

Evaluating and Assessing for Learning.

New Jersey: Nichols Publishing Company.

Kemendikbud. 2014. Peraturan Menteri Pendidikan dan Kebudayaan Nomor 14 Tahun 2014 tentang Kerja Sama Perguruan Tinggi.
Kirkpatrick, Donald L and Kirkpatrick, James D. 2009. Evaluating Training Programs. Berrett-Koehler Publishers

Kizlik, Bob. 2012. Measurement, Assessment, and Evaluation in Education. http://www.adprima.com/measurement. htm. Diunduh pada tanggal 10 Januari 2017.

Oxford University. 2015. International Trends in Higher Education. Oxford UK: University of Oxford International Strategy Office

Ravitz, Alan D. et al. 2013. Systems Approach and Systems Engineering Applied to Health Care: Improving Patient Safety and Health Care Delivery. JOHNS HOPKINS APL TECHNICAL DIGEST, VOLUME 31, NUMBER 4 (2013).

Republik Indonesia. 2012. Undang-Undang No 12 Tahun 2012, tentang Pendidikan Tinggi.

Safari. 2008. Penilaian Pembelajaran Berdasarkan KTSP. Jakarta: Balitbang Depdiknas.

Schindler, L., Puls-Elvidge, S., Welzant, H., \& Crawford, L. (2015). Definitions of Quality in Higher Education: A synthesis of the literature. Higher Learning Research Communications, 5(3), 3-13.

Suharsimi Arikunto, dan Cepi Safrudin. 2009. Evaluasi Program Pendidikan. Jakarta : Bumi Aksara

UNICEF. 2000. Defining Quality in Education. A paper presented by UNICEF at the meeting of The International Working Group on Education Florence, Italy June 2000. 